\title{
Features of Mental Stability of Security Department Staff with Different Duration of Service in the Penal System of the Russian Federation
}

\author{
PAVEL V. POTEMKIN \\ Vologda Institute of Law and Economics of FSIN Russia, Vologda, Russian \\ Federation
}

ORCID: https://orcid.org/0000-0001-5989-3884, e-mail: pahantus1988@mail.ru

\section{KONSTANTIN B. MALYSHEV}

Vologda Institute of Law and Economics of FSIN Russia, Vologda, Russian Federation

ORCID: https://orcid.org/0000-0003-2985-3341, e-mail: konbormal@mail.ru

\section{NIKOLAI G. SOBOLEV}

Branch of the Academy of Management of the Ministry of Internal Affairs of Russia «Bolshevo", Moscow, Russian Federation

ORCID: https://orcid.org/0000-0001-6101-7437, e-mail: sobolev-nikolay@mail.ru

\section{ALEKSEI M. CHIRKOV}

Vologda Institute of Law and Economics of FSIN Russia, Vologda, Russian Federation

ORCID: https://orcid.org/0000-0003-2256-9858, e-mail: chirart@yandex.ru

\footnotetext{
Abstract

Introduction: the article considers one of the urgent issues of legal psychology - the disclosure of the mechanisms of psychological stabilityin employees of security department of correctional institutions. Since the professional activity of security department employees has a sociogenic and stressful nature due to a number of parameters, the predominance of the impact of stress factors over the mechanisms of mental stability in many cases leads to negative implications such as the development of psychological burnout, social maladjustment and personality deformation. Aim: to determine internal mechanisms that reduce adaptive capabilities and factors that promote them, to study the features of psychological resistance to the action of social and stress factors in the security department employees, depending on the length of their service. Methods: we study the mechanisms of psychological stability of employees and the parameters of models of stress states with the use of the following methods: "Neuropsychic stability" ("Forecast") technique developed by V.Yu. Rybnikov (1990), a method for assessing professional burnout developed by C. Maslach and S. Jackson (1986), innovative multifactor methods for assessing basic professional typologies of stress and spirituality of an individual according to K.B. Malyshev (2021). Conclusions: the results of the study show that social stress among security personnel is one of the most traumatic forms of stress and it corresponds to the concept of professional stress. Moreover, the essence of the concept of psychological stability is associated with the study of subjective features
} 
of the phenomenon of disequilibrium of life activity - stress. Stress reflects the entire range of basic conditions - health and development, maladjustment and pathology. The data obtained in the study indicate the disharmonic nature of psychological adaptability (pseudo-adaptation) to the action of social stressors in employees with ten years of service experience. At the same time, the majority of respondents, in contrast to employees with a period in service of up to five years, have basic professional types of stress and spirituality, which indicates a low level of their socio-moral value orientations. This makes it necessary to develop innovative approaches to the prevention of professional stress and burnout among employees at all stages of their professional activity on the basis of the subjectsubject paradigm in the development of the intention to form spiritual and moral values in an individual.

Keywords: adaptation; basic profile of types of professional spirituality; basic profile of types of professional stress; inner world; correctional institutions; personality; multi-factor analysis; negative emotional states; professional burnout; penitentiary institutions; professional activity; mental and psychological stability; mental resources; coping behavior; social and professional stress; stressors; stress resistance; security department employees; consistency; terms of service; theory of functional systems according to P.K. Anokhin; penal system.

19.00.06 - Legal psychology.

For c it ation: Potemkin P.V., Malyshev K.B., Sobolev N.G., Chirkov A.M. Features of mental stability of security department staff with different duration of service in the penal system of the Russian Federation. Penitentiary Science, 2021, vol. 15, no. 3 (55), pp. 659-668. DOI 10.46741/2686-9764-2021-15-3-659-668.

\section{Introduction}

It is known that professional activity carried out in socially stressful conditions is a factor that determines dynamic transformation of psychological constants in an individual, which leads to the formation of one of the elements from the triad of functional states - mental development, adaptation or maladjustment. Social stress is understood as the socio-psychological transformation of society, various social communities, institutions and an individual; such transformation occurs under the influence of changes in the culture, politics and economy of the state. The penal system, being a special social institution, imposes increased requirements on the activities of correctional officers whose work reflects the specifics of social stress of an extreme socio-psychological nature. The professional activity of correctional personnel, especially employees of security departments, is considered to be the most stressful, since it is carried out in special and continuing socio-stressful conditions that determine changes in interaction in the "subjectsituation" system.

It is believed that the states of mental stress in the employees of the penal system result from the impact of specific and significant social stressors for the individual and at the same time are determined by a decrease in the level of general and selective specific stress resistance of the individual, which primarily includes psychological stability. Psychological, or rather mental, stability of a person in any field of activity is an integral phenomenon that contains stress resistance and similar concepts: emotional stability, resilience, tolerance to stress, as well as a generalized and differentiated construct that determines the measure of resistance to the negative influence of a fairly wide range of potentially stressful stimuli.

There is an opinion that mental stability of persons engaged in extreme activities is inversely dependent on the nature, intensity and duration of the action of stressors. M.Sh. Magomed-Eminov, on the contrary, believes that the main stressful factor in extreme situations is the discrepancy between human nature and those professional tasks one has to perform. According to L.A. Kitaev-Smyk, this circumstance leads to psychological burnout, which he understands as the "burnout of the soul".

All scientific sources note that the dynamics of psychological (professional) burnout corresponds to the stages and phases of the development of psychological stress (mobilization, resistance and exhaustion). Taking this into account, as well as the pronounced nature of the specifics of extreme factors in the activities of security department employees, we believe it is more acceptable to consider this form of social stress [3; 12] and burnout as professional stress. Most authors point out that stress in employees is a form of professional deformation that occurs under the influence of a protective mechanism for preserving emotional 
resources. As a result of its inefficiency, mental resources are depleted, and maladjustment states are developing. They arise as a result of the "breakdown" of the barrier of mental adaptation under the influence of extreme factors, which include the threat to life, use of firearms, high level of responsibility, monotony, violation of biorhythms (working in shifts), etc. Their influence is potentiated by social stressors of mixed genesis - discriminatory, environmental and role-based, difficulties of self-realization and achieving success, etc.

The leading role in mental stability belongs to socio-psychological characteristics of an individual and their preparedness (basis) for a particular stress effect. Scientific literature presents a wide range of personal psychological factors involved both in the development of adaptation processes in correctional officers and determining the maladjustment characteristics of occupational stress. In the formation of mental stability, in professional development and self-improvement of employees in recent years, special attention is paid to the psychological determinants of spirituality and the characteristics of the value sphere. The negative characteristics of professional stress noted in most studies with the description of its deficient mental conditions in correctional staff are replaced by a subject-subject approach and are characterized by a transition from the reactive paradigm of stress to the transactionalist and spiritual paradigm. This allows us to study personal features of employees and the dynamics of their mental stability as professional transformations that reflect both signs of professional destructions and positive changes in the behavior strategy and personal resources for overcoming professional stress and deformations.

We should also note the inconsistency of data on the nature of changes and mechanisms of mental stability of security department employees at different stages of service and the lack of methods for assessing the basic constants of professional profiles of stress reactivity of the individual, corresponding to the specifics of the transformation of professional spiritual and value states. In this regard, a comprehensive approach to the study of the mechanisms of mental stability among security department officers in a correctional institution, depending on the duration of their service, seems relevant and timely.

Results

The analysis of scientific data shows two fundamentally important patterns according to which the mental state of correctional institution employees is changing - the dependence of the occurrence and degree of severity of professional deformation of the individual on the length of their official activity and the close relationship of defects in the attitude toward the profession with specific changes in all substructures (spheres) of the personality. Despite the explicable differences in the data on the length of service corresponding to the emergence of mental stress (the first stage of professional stress), in most studies they were registered in employees at the initial stages of service - in the range from one to five years $[(9 ; 13-15 ; 17 ; 18]$. An increase in mental stability that corresponds to the adaptation of employees to the service (the stage of resistance), and its violations are detected, as a rule, at the stages from 5 to 10 or more years, which correspond to the stage of exhaustion. At the initial stage, professional stress is expressed in negative emotional states, manifested in a decrease in mental activity, fear, aggressiveness, a decrease in cognitive functions and self-development ability, loss of self-control and panic reactions, fatigue and uncertainty, anxiety and apathy, feeling of doom and despair, stupor, depression or euphoria, etc. [13-15]. These conditions correspond in detail and in phases to the symptoms of the development of deficient mental states, which eventually lead to a decrease in the effectiveness of professional activity [17]. Numerous sources indicate that with the loss, decrease and lack of coping behavior resources, the intensity of deficient mental states increases, which become a trigger for chronic professional stress, the final scenarios of which are neuropsychic and psychosomatic disorders; persistent or incomplete adaptation and social pathology - professional deformation. The latter option indicates the pathological orientation of the psychological transformation of the individual, leading to the development of deviations and professional degradation [7-9; 13; 17].

In order to specify periods of changes in mental sustainability typical of the deficit mental states, and the severity of occupational stress, we conducted a study of integrative indicators of mental stress and psychological burnout in employees of security department of the Directorate of FSIN Russia for the Vologda Oblast depending on the period (duration) of their service (tab. 1). 
Table 1

Average values of the indicators of neuropsychic stability in employees of security department with different work experience

\begin{tabular}{|l|c|c|c|c|}
\hline \multicolumn{1}{|c|}{ Length of service } & Average values & Standard deviation & U emp. & Level of statistical significance \\
\hline Up to 5 years $(n=25)$ & 5.1 & 0.9 & \multirow{2}{*}{129} & $p \leq 0.01$ \\
\hline From 5 to 10 years $(n=25)$ & 6.3 & 1.0 & & \\
\hline
\end{tabular}

The low level of average indicators of neuropsychic stress in a group of employees with five to ten years of service experience indicates the absence of significant violations of mental stability. The obtained data allow us to consider the mental state of security department employees with a long service experience as positive. This may indicate that the increase in the overall adaptive capacity and the use of protective (coping) behavior patterns while reducing the possibility of mental breakdowns alongside the increasing duration of the time in service. This suggests that the initial stage (tension) of professional stress, noted when an individual enters professional activity in the majority of employees from the group with up to five years of work experience, is replaced by the development of psychological stability as they acquire experience in the service, that is, there is a stabilization of the mental state that corresponds to the dynamics of the second stage of resistance due to the inclusion of psychological resources of resistance to stress.

The parameters of mental stability in this group of respondents are characterized by low indicators of emotional exhaustion, in contrast to the average values for most employees from the group with up to 5 years of service experience (tab. 2).

Table 2

Average values of the integrative indicators of professional burnout among employees with different work experience (according to the method of C. Maslach, S. Jackson)

\begin{tabular}{|l|c|c|c|c|c|}
\hline \multicolumn{1}{|c|}{ Scales } & \multicolumn{2}{|c|}{$\begin{array}{c}\text { Employees of the security } \\
\text { department, duration of } \\
\text { service under 5 years (n= 25) }\end{array}$} & $\begin{array}{c}\text { Employees of the security } \\
\text { department, duration of service } \\
\text { from 5 to 10 years (n = 25) }\end{array}$ & $\begin{array}{c}\text { Level of statistical } \\
\text { significance }\end{array}$ \\
\cline { 2 - 5 } & $\begin{array}{c}\text { Average } \\
\text { value }\end{array}$ & Standard deviation & $\begin{array}{c}\text { Average } \\
\text { value }\end{array}$ & Standard deviation & \\
\hline Emotional exhaustion & 15.3 & 3 & 7.1 & 2.5 & $\mathrm{p} \leq 0.01$ \\
\hline Depersonalization & 5.8 & 2.7 & 5.4 & 5.3 & $\mathrm{p} \leq 0.05$ \\
\hline $\begin{array}{l}\text { Reduction in personal } \\
\text { accomplishment }\end{array}$ & 36.2 & 2.2 & 39.1 & 6.9 & $\mathrm{p}>0.05$ \\
\hline
\end{tabular}

At the same time, the average values of the indicators showing a reduction in personal accomplishment in the group with an experience of 5 to 10 years are within the normal range, while the indicators on the "depersonalization" scale were higher on average (for 14 out of 25 employees). These data indicate the inclusion of psychological defense mechanisms in the form of partial suppression of emotions in response to prolonged and excessive traumatic effects. According to the majority of authors, any form of adaptation typical of the second stage of stress can maintain the resilience of a person for a long time even in conditions of a long-term course of a stressful state through mechanisms of minimizing the stressor. According to A. L ngle, these mechanisms prevent further violations of the existential attitude of an individual. The results of our study correlate with the data of other authors on the adaptation of security department staff to the action of extreme factors and on the possibility of simultaneous formation of negative (maladjustment) manifestations of professional stress [16].

Since this type of stress develops in healthy individuals and includes a complex set of psychological rearrangements leading to professional personality deformation and other changes, it is advisable to consider them as professional transformations of (stress-induced) 
mental states [16]. E.L. Trofimova points out that transformations can be both positive and negative, and their ratio changes with increasing service experience. Moreover, the author considers the positive changes occurring in the process of professional activity of the staff as personal resources for overcoming deformations [16].

The obtained results of psychological diagnostics can be interpreted as an increase in the mental stability of the staff with their increasing time in the service, since studies, both our own and by other authors, indicate a pronounced psycho-emotional stress in employees at the initial stages of professional activity. At the same time, the results allow us to speak about the disharmonious nature of adaptation to professional stress, since along with mental stabilization, the staff with long service experience have negative manifestations of professional deformation that go along the path of depersonalization. This phenomenon of transformation of stress characteristics that replace each other is called the "price" of adaptation.

The analysis of psychological constants that determine the essence and features of the mechanisms of professional stress development in correctional staff, as well as psychological drivers of stress resistance required for explaining the causes of the changes, indicates the complexity and ambiguity of these phenomena, which is reflected in the variety of viewpoints of researchers regarding their nature, structure, mechanisms of occurrence, etc. For instance, E.V. Rasponin believes that resistance to professional stress and its internal sources is due to the personal resources of correctional officers - behavioral and problemoriented coping strategies, among which an important place, according to the researcher, belongs to coping with self-control of behavior and problem solving, emphasizing the role of a value-semantic complex that forms a constructive model of psychological resources of resistance to stress. It includes such personal qualities as a high level of will development, an internal locus of control, emotional stability, social orientation, balance, resistance, fortitude, self-knowledge, etc. [13]. In other studies, the following internal factors of stability are pointed out: preservation of personal identity (self-identity) [7], which plays a major role in the processes of meaning formation, self-determination and group differentiation, the state of stimulating and meaning-forming functions of motivation, the insufficiency of which is accompanied by an intrapersonal psychodynamic conflict in the personality of employees [14], an adequate ratio of personal accentuations with the emotional component of individual forms of behavior control [6]. Generalization of the experience of Western and Russian authors, on the other hand, gives reason to believe that the significant internal triggers of professional stress are found in negative psychological experiences (decreased interest, indignation, personal frustration, etc.), the psychological stability of the personality of a correctional institution employee (its functionality) is considered as a system reflecting the ratio of subject-personal interactions and intrapersonal rearrangements of the individual's set of resources.

The majority of the works of Russian and foreign researchers reveal a mismatch (contradiction) between professional activity and the state of the emotional and other spheres of the personality of employees. Despite the value of empirical data and the tendency to clarify integrative properties of psychological stability of an individual (internal drivers of stability and sources of stress) as coping resources, their disadvantage consists in the use of the biologizing methodology of the reactive stress paradigm. And if earlier the study of employees' psychological stability was limited mainly to the analysis of emotional, volitional, intellectual and other components of the psyche involved in the complex of professional burnout, in recent years the number of interdisciplinary studies using postnon-classical methodology has been growing [3-5; 11; 12; 18].

Going beyond the linear approach (the $S \rightarrow$ $R$ paradigm) to the study of the psychological stability of correctional staff is reflected in the development of psychological monitoring of professional stress (professional burnout) based on a multi-paradigm approach to analyzing the dynamics of the existential, activitybased and resource-based components of the subjective reality (inner world) of a correctional institution employee [18]. This revealed the dynamic nature of changes in the structural organization of an individual and the spiritual and moral orientation of the individual in the process of service. The appeal to the higher mental instances of the individual allowed us to build a binary model of the personality typology for a correctional institution employee in the form of an "energetic" subject with a high level of professional motivation and an "exhausted" 
one with a low level of motivation and signs of psychological burnout; we also identified motivational determinants depending on the length of service $[13 ; 14 ; 16 ; 18]$. Thus, the values of knowledge and the motives of involvement in the team, and recognition - the values typical of an employee at the initial stages of service, are replaced by the values of freedom and the motives of "leadership", "connections", "money", "adherence to the traditions", which positively correlate with the manifestations of professional deformation; this indicates a regression of spiritual and moral phenomena in employees with long service experience [14]. However, despite the available data on the role of spirituality as a psychological component (resource) of the viability and resilience of an individual, there are still no fundamental studies of spiritual sources and factors contributing to the formation of psychological stability in correctional officers.

Thus, the analysis of the scientific literature data indicates a clear lack of knowledge about the etiopathogenesis of occupational stress and the internal mechanisms that determine the transformation of the psychological stability of employees in the development of adaptation to professional stressors and the processes of professional deformation. There is still no clear data on the typological (selective) professional vulnerability of employees to external and internal stress factors. There is also an undeveloped theoretical basis in the field of analyzing the spiritual resources of the individual as factors promoting the development of a psychological model of the resistance of security department staff to professional stress. Moreover, there are practically no studies on the use of the positive (developing) potential of stress in correctional officers. At the same time, according to P.K. Anokhin's theory of functional systems, the reduction or elimination of stress from any sphere of human activity deprive them of general and specific (professional) development, causing stagnation of the "functional system of a professional" [1]. Since professional qualities in security department staff are formed in stressful conditions, their elimination suppresses the positive effect of stress, deprives an individual of the opportunity to develop not only the properties and qualities of a professional, but also a stable adaptation. Therefore, in order to reveal the phenomenon of mental stability, a more indepth search and interpretation of the essence of professional stress itself and the individual psychological characteristics of employees are necessary on the basis of the synchresis of natural and humanitarian methods of studying subjective reality

In this regard, for the purpose of a more indepth analysis of the features of mental stability in security department staff, at the second stage of the research, we studied stress characteristics of employees' personality on the basis of models of a typological system-based approach to the study of professional stress and spirituality using two valid methods: "Types of professional stress-inducing personality" and "Types of professional value-based spirituality of personality" according to B. Malyshev (2021). The new diagnostic tools - methods for assessing the types of the profile of stress of the individual and the profile of the professional value-based spirituality of the individual correspond to the three-dimensional basic typology of the professional orientation of the individual according to V.A. Hansen [2], which complements the analysis of psychological characteristics of correctional officers. We should note that the basic methodology for assessing professional value-based spirituality of employees is used to measure the intentionality (aspiration) to values and value orientations, which are the most important psychological characteristics of an individuals' spirituality [11]. Despite the reductionist nature of the method (elimination of the higher constants of the phenomenon of spirituality), its use from the post-non-classical standpoint adds to the features of the mechanisms of psychological stability in the professional activities of correctional officers. Spirituality is understood as a stable and dynamic psychological ideal-semantic formation (core, integrator), which performs a system-forming function in the formation of the integrity of the mental world of the individual and plays the role of regulator of human behavior and activity, responsibility for one's actions and relationships with other people $[5 ; 10 ; 12 ; 15]$. Spirituality reflects self-development and self-realization through the search for the meaning of life, acceptance of the highest values of human existence and moral norms of the community, as well as following the highest examples of human culture $[5 ; 10]$.

As can be seen from Table 3, the group with up to five years of service experience is dominated by employees with the types of enterprising/managerial, (24\%), social/"empathic" (24\%) and realistic/"occupational" (20\%) professional and stress-related personality profiles. In the 
group with 5 to 10 years of service experience, there are more respondents with the models of occupational (working) and normative professional profiles of personal stress (31\% and $27 \%$, respectively), with a smaller number of people with "managerial", research and "empathic" profiles. The share of persons with types of intellectual-research and artistic-aesthetic professional profiles of personality stress in this group was $12 \%$ and $8 \%$, respectively.

Table 3

Comparative characteristics of professional types of personal stress in employees of the security department with different service life

\begin{tabular}{|l|c|c|c|c|}
\hline $\begin{array}{c}\text { Three-factor } \\
\text { occupational } \\
\text { personality typological } \\
\text { model (according to J. } \\
\text { Holland) }\end{array}$ & $\begin{array}{c}\text { Types } \\
\text { of personality according to } \\
\text { stress }\end{array}$ & $\begin{array}{c}\text { Employees } \\
\text { with up to 5 } \\
\text { years of service } \\
\text { experiencen=25 }\end{array}$ & $\begin{array}{c}\text { Employees } \\
\text { with 10 years } \\
\text { of service } \\
\text { experience } \\
\mathbf{n = 2 5}\end{array}$ & $\begin{array}{c}\text { Level of } \\
\text { statistical } \\
\text { significance }\end{array}$ \\
\hline Enterprising type & Managerial stress & $24 \%$ & $11 \%$ & $\mathrm{p} \leq 0.01$ \\
\hline Investigative type & Research stress & $8 \%$ & $12 \%$ & $\mathrm{p} \leq 0.05$ \\
\hline Social type & Empathic (ethical) stress & $24 \%$ & $11 \%$ & $\mathrm{p} \leq 0.05$ \\
\hline Realistic type & Occupational (working) stress & $20 \%$ & $31 \%$ & $\mathrm{p} \leq 0.05$ \\
\hline Conventional type & Regulatory stress & $10 \%$ & $27 \%$ & $\mathrm{p} \leq 0.01$ \\
\hline Artistic type & Aesthetic stress & $4 \%$ & $9 \%$ & $\mathrm{p} \leq 0.05$ \\
\hline
\end{tabular}

For people with up to five years of experience, the main stressors are the mismatch of their own ideas and their role in professional activity with the established regulations of service in the penal system, experiences related to the moral and ethical side of the profession and difficulties in adapting to workloads. A larger number of employees in the group with service experience from 5 to 10 years with occupational and normative professional profiles of personal stress indicates their dissatisfaction with their financial situation, a decrease in motivation for service, an increase in intrapersonal and interpersonal conflicts and problems related to responsibility and the need to perform professional duties. We can assume that as the service progresses, the change in the professional-stress type of personality occurs through the dominance of models of realistic/occupational (working) and conventional/normative types of professional stress, which indicates the formation of depersonalization [11].

The assessment of the types of professional value-based spirituality was carried out according to six basic personality types (managerial, cognitive, ethical, material, moral and aesthetic). In the group of employees with up to 5 years of service experience, in general, the predominance of managerial, ethical and material types was found, which made up $24 \%$, $32 \%$ and $20 \%$ of the total number of respondents, respectively. Among employees with service experience from 5 to 10 years, the maximum number (32\%) of persons with a material profile of values was revealed, and the values of indicators of the cognitive type of spirituality were twice higher than among respondents with service experience of up to five years (16\% vs. $8 \%$ ). Among employees with long service experience, there are more people with moral and aesthetic profiles of professional spirituality in comparison to the group of young employees (20\% and $11 \%$ vs. $12 \%$ and $4 \%$ ). At the same time, the number of people with a moral type of spirituality (12\%) was significantly lower in comparison with the group of young employees (32\%) and the organizational type ( $9 \%$ vs. $24 \%$ ). We should note that the obtained data characterizing the features of the percentage distribution of certain types of professional value spirituality in both groups of employees have similarities with the characteristics of professional basic orientation parameters and personality stress. Consequently, in a group with service experience of up to 5 years, most of the employees have such spiritual values as morality, justice and empathy with a desire for organizational activity and motivation to achieve material resources (goods) in combination with expressiveness, authority and aggressiveness, which leads to stressful situations and a decrease in mental stability. At the same time, the distribution of types of spiritual values in the group of employees with service experience from 5 to 10 years indicates a pro- 
nounced pragmatic spiritual orientation of the majority of respondents; $87 \%$ of respondents did not have indicators that show the orientation toward spiritual and moral values, and only $36 \%$ showed a desire to comply with normative (moral) rules and requirements and solve professional problems.

The obtained information about the close relationship between indicators of the orientation of employees toward spiritual values and the changes in the profiles of professional stress is confirmed by scientific data indicating that, along with the regulating higher mental functions, spirituality is a factor (resource) promoting psychological stability, vitality and hardiness in an individual $[4 ; 10 ; 12 ; 15 ; 17]$. The decrease in the integral moral and spiritual potential of employees - the level of spiritual consciousness according to V.P. Zinchenko [5], reflecting the transformation of the goal-setting (orientation) of the individual, testifies (from the position of the theory of functional systems of P.K. Anokhin [1]) that overcoming professional stress among security department staff with service experience from 5 to 10 years is carried out according to a maladjustment type (pseudo-adaptation). Because the increase in mental stability and certain indicators that reflect a reduction in the manifestations of professional stress in this group as a whole is accompanied by a negative transformation of stress profiles and a decrease in moral and spiritual values of an individual, which indicates the formation of depersonalization (psychological deformation and relative spiritual deficiency). It is for a reason that scientific literature uses the terms "destructive", "deficiency" spirituality, despiritualization, etc. [12; 15; 17].

A number of authors indicate that consideration of the formation of spiritual and moral qualities in employees involves not only their study, but also the identification of the essence of the basic terms "spirituality", "ethics" and "morality" so as to design a scientifically substantiated system of psychological methods that determine the effectiveness of addressing the issues of integrative resistance of correctional officers to professional stress. Interdisciplinary and problem-oriented approaches to the disclosure and prevention of occupational stress based on the hierarchical principle of regulating the functional organization of psychological stability and hardiness will help to solve the problems of professional activity safety with a more scientifically substantiated study of the structure and function of the spiritual and moral principles of employees' personality. It can be proven by the data showing that the ability to think develops to the fullest extent at the spiritual level of personal development, reflecting life in the unity of its logical, mental and moral aspects, and the actions of an individual should be evaluated in the unity of one's behavioral, psychological and moral components [3-5; 10; 15].

\section{Conclusions}

The presented theoretical and empirical results of the study confirm the data of other studies on the differences in the severity of stress states depending on the duration of the service of employees in penitentiary institutions and the development of negative manifestations of professional stress. At the same time our research findings add to the existing views on the mechanisms that ensure psychological stability and the process of adaptation to stress. The revealed low level of stress manifestations in employees with ten years of service experience corresponds to external forms of adaptation (pseudo-adaptation) to the action of social stressors, which corresponds to the development of depersonalization.

The nature of transformational changes in the manifestations of professional stress and typological profiles of professional stress (vulnerability), along with the assessment of the spiritual and moral sphere, indicates the inclusion of the phenomenon of spirituality in the development of employees' adaptation to stressful influences, reflecting the features of protection mechanisms proceeding from the length of service of security department staff.

The results of the study provide the basis for constructing variable stage models of the states of psychological stability of correctional officers of security department at different stages of their official activities, which requires a comprehensive diagnostics of the ongoing transformations of the manifestations of professional stress and an assessment of psychological stability involving the dynamics of changes in the personal basic profiles of professional stress.

The article substantiates the importance of developing an effective integrative and targeted psychological prevention of negative consequences of professional stress (professional burnout) in employees at all stages of their professional activity on the basis of the subject-subject paradigm of development and the intention to form spiritual and moral values of the individual. 
The data we have obtained also indicate the need for further studies of mental stability on the basis of an interdisciplinary approach to revealing the features of selective formation and restructuring of the spiritual and moral sphere of an individual, which determines the dynamics of changes in the psychological stability of correctional officers to external and internal sources of professional stress.

\section{REFERENCES}

1. Anokhin P.K. Uzlovye voprosy teorii funktsional'nykh sistem [Key issues of the theory of functional systems]. Moscow: Nauka, 1980. 196 p.

2. Ganzen V.A. Sistemnye opisaniya v psikhologii [System descriptions in psychology]. Leningrad: Leningrad, 1984. $176 \mathrm{p}$.

3. Dolgova V.I., Vasilenko E.A. Social stress as a factor maladjustment personality. Sovremennye naukoemkie tekhnologii=Modern High Technologies, 2016, no. 8-2, pp. 303-306. (In Russ.).

4. Zhuravleva N.A. Psikhologiya sotsial'nykh izmenenii: tsennostnyi podkhod [Psychology of social changes: valuebased approach]. Moscow: Institut psikhologii RAN, 2019. 528 p.

5. Zinchenko V.P. Soznanie i tvorcheskii akt [Consciousness and creative act]. Moscow: Yazyki slavyanskikh kul'tur, 2010. $592 \mathrm{p}$.

6. Kadochnikova I.V., Sergienko E.A. Subjective and personal changes in the employees of the penitentiary system. Mir nauki. Pedagogika i psikhologiya=World of Science. Pedagogy and Psychology, 2020, vol. 8, no. 1, p. 49. (In Russ.).

7. Kozyreva T.S. Strukturnye komponenty identichnosti lichnosti s priznakami posttravmaticheskikh stressovykh sostoyanii: na primere sotrudnikov uchrezhdenii ugolovno-ispolnitel'noi sistemy: dissertatsiya na soiskanie uchenoi stepeni kandidata psikhologicheskikh nauk [Structural components of personality identity with signs of post-traumatic stress states: on the example of employees of institutions of the penal system: Candidate of Sciences (Psychology) dissertation]. Novosibirsk, 2009. 215 p.

8. Kopylova T.V. "Emotional burnout" as a form of professional deformation of the personality of an employee of the penal system. Pedagogika $v$ pravookhranitel'nykh organakh=Pedagogy in the Law Enforcement Agencies, 2003, no. 1, pp. 13-15. (In Russ.).

9. Krapivina O.V. Emotsional'noe vygoranie kak forma professional'noi deformatsii u penitentsiarnykh sluzhashchikh: dissertatsiya na soiskanie uchenoi stepeni kandidata psikhologicheskikh nauk [Emotional burnout as a form of professional deformation in correctional staff: Candidate of Sciences (Psychology) dissertation]. Tambov, 2004. 200 p. 10. Leont'ev D.A. Spirituality, self-regulation and values. Izvestiya Yuzhnogo federal'nogo universiteta. Tekhnicheskie nauki="Izvestiya SfedU. Engineering Sciences, 2005, no. 7, pp. 16-21. (In Russ.).

11. Malyshev K.B., Malysheva O.A. Osnovy psikhoalgebry [Fundamentals of psychoalgebra]. Kursk, 2021. $157 \mathrm{p}$.

12. Oboturova N.S., Chirkov A.M. Filosofsko-antropologicheskie osnovaniya metodologii psikhoterapii osuzhdennykh: monografiya [Philosophical and anthropological foundations of the methodology of psychotherapy of convicts: monograph]. Vologda: VIPE FSIN Rossii, 2019. 186 p.

13. Raspopin E.V. Psikhologicheskaya ustoichivost' $k$ vneshnim $i$ vnutrennim istochnikam stressa: na primere sotrudnikov ugolovno-ispolnitel'noi sistemy: dissertatsiya na soiskanie uchenoi stepeni kandidata psikhologicheskikh nauk [Psychological resistance to external and internal sources of stress: on the example of employees of the penal system: Candidate of Sciences (Psychology) dissertation]. Yekaterinburg, 2013. 190 p.

14. Rozhkov O.A. Motivatsionnye determinanty professional'noi deformatsii sotrudnikov ugolovno-ispolnitel'noi sistemy: dissertatsiya na soiskanie uchenoi stepeni kandidata psikhologicheskikh nauk [Motivational determinants of professional deformation of employees of the penal system: Candidate of Sciences (Psychology) dissertation]. Ryazan, 2013. $219 p$.

15. Samoilik N.A., Klimova N.V. Spiritual and moral foundations of professional and value-based orientations of employees of the penal system. In: Sovremennaya psikhologiya: materialy IV Mezhdunarodnoi nauchnoi konferentsii (g. Kazan', oktyabr' 2016 g.) [Modern psychology: proceedings of the 4th International Scientific Conference (Kazan, October 2016)]. Kazan: Buk, 2016. Pp. 37-40. (In Russ.).

16. Trofimova E.L. Professional transformations of detention centers officers. Psikhologiya $v$ ekonomike $i$ upravlenii=Psychology in Economics and Management, 2016, vol. 8, no. 1-2, pp. 36-42. (In Russ.).

17. Tyulyupergeneva R.Zh. Vliyanie defitsitarnykh psikhicheskikh sostoyanii na formirovanie professional'noi deformatsii lichnosti sotrudnikov pravookhranitel'nykh organov: na primere Respubliki Kazakhstan: avtoreferat dissertatsii na soiskanie uchenoi stepeni kandidata psikhologicheskikh nauk [Impact of deficiency mental states on the development of professional deformation of the personality of law enforcement officers: case study of the Republic of Kazakhstan: Candidate of Sciences (Psychology) dissertation abstract]. Moscow, 2017. 196 p.

18. Cherkasova M.A., Pozdnyakov V.M. Psikhologicheskii monitoring professional'nogo vygoraniya sotrudnikov ugolovno-ispolnitel'noi sistemy Rossii: monografiya [Psychological monitoring of professional burnout of employees of the penal system of Russia: monograph]. Vologda: VIPE FSIN Rossii, 2016. 135 p.

\section{INFORMATION ABOUT THE AUTHORS}

PAVEL V. POTEMKIN - lecturer at the Department of Legal Psychology and Pedagogy, Psychological Faculty, Vologda Institute of Law and Economics of FSIN Russia, Vologda, Russian Federation, ORCID: https://orcid.org/0000-0001-59893884, e-mail: pahantus1988@mail.ru 
KONSTANTIN B. MALYSHEV - Doctor of Sciences (Psychology), Associate Professor, professor at the Department of Legal Psychology and Pedagogy, Psychological Faculty, Vologda Institute of Law and Economics of FSIN Russia, Vologda, Russian Federation, ORCID: https://orcid.org/0000-0003-2985-3341, e-mail: konbormal@mail.ru

NIKOLAI G. SOBOLEV - Candidate of Sciences (Psychology), Associate Professor, Associate Professor of the Department of Training the Leading Personnel of Internal Affairs Bodies, Branch of the Academy of Management of the Ministry of Internal Affairs of Russia «Bolshevo», Moscow, Russian Federation, OR-CID: https://orcid.org/0000-00016101-7437, e-mail: sobolev-nikolay@mail.ru

ALEKSEI M. CHIRKOV - Doctor of Sciences (Medicine), professor at the Department of Legal Psychology and Pedagogy, Psychological Faculty, Vologda Institute of Law and Economics of FSIN Russia, Vologda, Russian Federation, ORCID: https://orcid.org/0000-0003-2256-9858, e-mail: chirart@yandex.ru 